\title{
Enlarged Uterus
}

National Cancer Institute

\section{Source}

National Cancer Institute. Enlarged Uterus. NCI Thesaurus. Code C92773.

An increase in the overall dimensions or volume of the uterus compared to normal. 